\title{
POSSIBILITIES TO IMPROVE THE IMAGE OF FOOD AND ORGANIC PRODUCTS ON THE AP VOJVODINA MARKET BY INTRODUCING A REGIONAL QUALITY LABEL
}

\author{
Jelena A. Končar, Aleksandar B. Grubor, Radenko M. Marić*, Goran M. Vukmirović, Nenad S. Đokić
}

University of Novi Sad, Faculty of Economics in Subotica, 24000 Subotica,

Segedinski put 9-11, Serbia

\author{
${ }^{*}$ Corresponding author: \\ Phone: +38162278559 \\ Fax: +381214852900 \\ E-mail address: radenko.maric@ef.uns.ac.rs
}

\begin{abstract}
Internationalization processes affect the multiple increases in the supply of food and organic products in national markets, which reflects the increasing level of competition between imported products and products of national origin. Consequently, customers can choose from a very wide range of finished products for which they are not in a position to safely identify all aspects of quality and origin. The aim of the research is to identify obstacles and shortcomings of the existing supply of food and organic products on the market of AP Vojvodina, analyse the inclination of domestic customers to purchase products of national origin and determine customers' trust in the concept of product labelling as a confirmation of quality and geographical origin. The empirical research includes the examination of attitudes of 486 end consumers in the AP Vojvodina market in relation to their expectations and habits in purchasing food and organic products. The result of the research confirmed that a future regional quality label should combine indicators such as standardized product quality, confirmed composition of raw materials, freshness, geographical origin, brand and availability. Such quality label statistically significantly determines the consumers' choice when making a decision to buy food and organic products.
\end{abstract}

Key words: food products, organic products, quality labels, trust, purchasing habit, Verified origin from Vojvodina.

\section{INTRODUCTION}

Food and organic products are the most important component affecting the decision to purchase. Customers are most sensitive in terms of trust in their quality, composition of raw materials, the method of production, packaging, transport, storage and disposal. In order to clearly emphasize quality and environmentallyfriendly food and organic products, quality labels or geographical origin labels are introduced on the market. Quality labels guarantee the origin, quality and composition of the raw materials, i.e. they guarantee that the labelled products meet the eco-standards that are compliant with the requirements of the natural environment. However, Serbian market, especially the AP Vojvodina market, is still insufficiently dedicated to food and organic products labelling. The results show that the implementation of the labelling concept is at lower levels in the AP Vojvodina market compared with the countries of the developed market economy. Therefore, the key research question is to determine to what extent recognizable quality labels on the product or its packaging affects customers' expectations and their decision to 
purchase food and organic products. Expected results may encourage the AP Vojvodina competent institutions, producers, agricultural enterprises and trading companies to direct their activities towards the implementation of the labelling concept for products of proven national quality and origin.

Results of numerous studies (Petković et al., 2016; Končar and Leković, 2013; VanBerkum and Bogdanov, 2012; Vlahović et al., 2011) show that various factors affect the retail sector of food and organic products on the market of the Republic of Serbia after 2000, which are the result of the internationalization of the national market. The increased presence and market share of international trade chains led to a changed structure of the food products supply, including several times increased share of imported products in retail chains' range of products. The most widely used model of supply chain for food and organic products can be represented by a 80:20 ratio, which indicates that range of products of retail facilities on the market of AP Vojvodina and the Republic of Serbia includes at most $20 \%$ of products from local sources. i.e. of national origin, while at the same time the share of imported food products reaches $80 \%$ of the total range of products, observed through quantitative and value indicators (Končar et al., 2018).

As a result of such tendencies, food and organic products of domestic producers are significantly less available to consumers, especially in urban areas. Research conducted on the market of the Republic of Serbia (Vlahović et al., 2011) showed that the biggest issue (34\%) is that consumers do not trust foreign producers of food products in terms of designated level of quality, freshness, organic composition of raw materials and durability. On the other hand, when it comes to domestic products, consumers express dissatisfaction with high prices $(31 \%)$, insufficient supply and availability on the market $(21 \%)$ and inadequate marketing activities (8\%). Other studies (Lukić, 2012) confirm that current economic, social and environmental performances make it difficult to place food and organic products from local sources. Higher consumption and availability of products of national origin on the one hand contributes to the strengthening of the national/regional economy, as well as to the strengthening of the competitive position of domestic companies. In order to ensure that the market is sufficiently supplied with food and organic products of national origin, it is necessary to create an environment for cooperation of domestic agricultural, processing and trading companies as the "joint offer providers" in relation to international producers and retailers present on the market of AP Vojvodina. Vertical integration strategy (Končar et al., 2018; Avedian, 2018; Petković et al., 2016) can lead to an increase in the market share of domestic products in the national market, which is a prerequisite for changing the power relations between local-national and international (global) producers. In contrast, as an important determinant of choice between national and global brands, consumer ethnocentrism is also developing as a consumers' tendency to prefer and buy products from local sources rather than imported competing products (Grubor and Đokić, 2015; Veljković, 2009). Some research conducted on the regional market (Milin, 2018; Gašević et al., 2017; Marinković, 2017; Grubor and Đokić, 2015; Veljković, 2009) emphasize that the tendency towards ethno-centrism is the most pronounced in the segment of the supply of consumers and households with food domestic products of proven quality. In this regard, it is necessary to follow the examples of countries in a developed market economy and develop an appropriate system of indicators that would in the first place highlight the quality, greater availability of domestic products, and then enable the development of an adequate model for improving trust in the supply of domestic agricultural holdings and local producers, which currently do not exist on the market of the Republic of Serbia and AP Vojvodina. At the same time, the realization of such a complex strategy requires the definition of actual needs and willingness of end consumers to buy domestic food and organic products.

The subject of the research is the analysis of the possibilities of improving the place- 
ment and image of food and organic products on the market of AP Vojvodina through creating an environment for cooperation between domestic producers, farmers and retailers, and introducing a regional quality label, which would be a synonym for quality and fresh food and organic products, as a recognizable "joint offer" of domestic business entities - Verified origin from Vojvodina, in relation to imported products. The aim of the research is to identify obstacles and shortcomings of the existing supply of food and organic products on the market of AP Vojvodina, analyse domestic consumers' tendency to purchase products of national origin, and determine consumers' trust in the concept of product labelling as a confirmation of quality and origin. In the theoretical part of the research, the focus is on analysing the advantages and disadvantages of supplying a certain segment of the market with products of local origin, and determining the significance of consumers' trust in the composition of raw materials, freshness of products, origin, organoleptic properties, adequate packaging, availability and display, to the level of their perception of quality. The empirical part of the research is an analysis of the data collected by electronic and field survey on a sample of 486 end consumers about the place and manner of purchase and trust in the quality of food and organic products in several municipalities of AP Vojvodina. The collected and systematized data are the basis for identifying specific characterristics of demand and expectations of consumers in terms of purchase and expected properties of food and organic products.

\section{Literature Review}

Food and organic products represent the most sensitive segment of the modern supply chain. With their activities, producers significantly affect the natural cycles and the state of the natural environment, which is largely caused by unhindered technical and technological progress and production process. As environmental problems are higher, manufacturers are facing greater challenges in creating a quality and healthy food product (Stojanović and Ognjanov, 2012). These challenges involve large investments in research, ex- ploitation of raw materials, elimination of harmful substances, as well as efficient placement, advertising and emphasis of origin and quality.

Some recent studies (Ricci and Banterle, 2018; Stojanović and Ognjanov, 2012) indicate that respondents highly appreciate the safety of food products, considering that food placed on the market must be manufactured to the highest industry standards (hygiene, composition of raw materials, perishability, durability, etc.). At the same time, the country of origin is a very important feature, i.e. respondents find it very important to know the region from where the food originated along with adequate quality and origin labels on the product itself or on the packaging.

Researchers, on the one hand, attribute the supply of food and organic products from local sources to ethnocentrism (Grubor and Đokić, 2015; Schnettler et al., 2011; Veljković, 2009). Ethnocentrism is the pre-dominant concept of purchasing primarily in the rural population that identifies with local producers and buys their products as a form of loyalty or belonging to the region (Jan et al., 2018; Krishna and Balasubramanian, 2018). On the other hand, the prevailing attitude concerning domestic products is that consumers are more sure of the origin of raw materials, the organic composition, freshness, quality, minimized impact of pesticides, especially in fruits and vegetables, etc. (Vlahović, 2011). The study by Vermeir and Verbeke (2006) conducted on the global market confirmed the strong correlation in a positive direction between consumers' trust in the quality of traditional (local) food and purchase intentions. However, despite the concept of ethnocentrism and greater trust in the quality of food and organic products from local sources, their insufficient availability on shelves in retail facilities is still explained by low purchase intentions, regardless of the fact that consumer attitudes may be positive (Vermeir and Verbeke, 2006).

Although there is an increase in the level of consumers' positive attitudes on the purchase of products from local sources (e.g. traditional food), the intensity of the intention to buy does not record a sig- 
nificant growth (Leda and Gomes, 2017; Goldman and Hino, 2005). The demand limitation is primarily affected by the lack of consumers' trust in the existing aspects of standardization and ways of labelling the quality and origin of domestic food and organic products (Martić Kuran and Mihić, 2014; Vlahović, 2011), hygienic conditions of production and transport, etc. (Stojanović and Ognjanov, 2012). It is argued that the uncertainty about how the products are produced and packaged may even result in different forms of market withdrawal such as downshifting and voluntary simplicity among groups that otherwise constitute an attractive target group for ecological products (Kraleva, 2017; Peyer et al., 2017). Combined with the effect of consumers' price elasticity on relatively higher prices of observed products due to the low economies of scale resulted in decreased sales. Apart from this, consumers point out that promotional support to domestic products as well as their availability and display on retail facility shelves are organized at a low level, which gives global brands better visibility and a stronger image as determinants when deciding on purchasing. According to the perceived consumers' attitudes (Leda and Gomes, 2017; Vlahović, 2011), the choice to buy brands of global food manufacturers has a foothold in both attractive and customized packaging and packing, better organoleptic properties, which, with a relatively lower average price, make these products more competitive in relation to products of national origin.

Regarding the AP Vojvodina market, the food product supply system has undergone significant changes in the last decades, especially due to the accelerated process of trade internationalization. The launching of foreign retail chains in the domestic market since 2000 has modified the way of purchasing food, organizing the supply chain and the food standard of the population, primarily in urban areas. The traditional habits of buying food products on green markets, i.e. purchasing directly from agricultural producers, become less represented. By reducing the share of direct consumer supply with food products from agricultural producers, additional space for leading retail chains is created, which can offer a variety of food products of standardized quality, which are purchased from renowned foreign and national producers. Retail chains offer products that through economies of scale can bring about maximizing profits within the product category and increasing market share. Hence, their focus is on finding a source of supply that will enable the highest return on the assets involved, which most often affects the absence of food and organic products of local origin, and especially those that can be offered by small and medium-sized enterprises relying on the production of traditional food.

Numerous researchers (Patterson, 2018; Brčić-Stipčević et al., 2011; Kopić et al., 2008) believe that stores controlled by multi-outlet retail chains are the dominant place for the purchase of fresh foods, especially fruits, vegetables, meat and meat products, milk and dairy products by consumers living in urban areas. In this regard, it is necessary to create an adequate model that would stimulate integration of domestic companies with a focus on increasing standardization of products and their quality, while promoting promotional activities related to packaging, availability and display of products through innovative methods and techniques of placements. Label of quality and product origin would be an element of supply package that could potentially bring together all the efforts of domestic companies in terms of improving the image of products from local sources. End consumers show increasing interest in all aspects of food quality, while recognition and safety appear as the main motives of purchasing (Grubor et al., 2014). The label in this sense guarantees quality and compliance with food safety standards (Stojanović and Ognjanov, 2012). Therefore, this research, which is primarily empirical, deals with the improvement of the competitiveness of domestic producers, farmers and trade companies in the AP Vojvodina market, by learning about the expectations and attitudes of end consumers in the selection of food and organic products. Given the aspects of the theoretical analysis of the research subject, it is possible to isolate several indicators that are crucial for consumers' expectations in terms of trust in 
the quality and origin of food and organic products: 1) exogenous indicators or demographic variables, such as income, level of education, number of household members, place of residence and share of food costs in total expenditures (Leda and Gomes, 2017; Grubor and Đokić, 2015; Grubor et al., 2014; Stojanović and Ognjanov, 2012; Verbeke, 2005), 2) purchase process indicators related to the place of purchase, brand, product availability and display (Šojić, 2017; Lukić, 2012; Vlahović et al., 2011), 3) characteristics of products concerning quality, composition of raw materials, freshness, geographical origin and price (Vlahović et al., 2011; Vermeir and Verbeke, 2006), and 4) the effect of product labelling or the introduction of a regional quality label (Jan et al., 2018; Stojanović and Ognjanov, 2012).

\section{MATERIALS AND METHODS}

\section{Aim and Hypothesis}

The aim of the research is to analyse indicators that affect the expectations of end consumers in the purchase of food and organic products. In this context, the main task of the research is to determine whether the introduction of a regional quality label - Verified origin from Vojvodina would affect customers' purchasing habits and whether such a quality label would be a synonym for quality and fresh food and organic products. A key research question is whether competitiveness of domestic economic entities would be improved by the introduction of a regional quality label, which would, through a recognizable "joint offer", more effectively compete with imported products. The goal thus established is operationalized through four basic research hypotheses:

$\mathbf{H}_{1}$ : Income, level of education, number of household members, place of residence and the share of food costs in total household expenditures have a statistically significant impact on the level of consumers' expectations about product features and the purchase process of food and organic products itself.

$\mathbf{H}_{2}$ : Expectations about the place of purchase, brand and availability of products have a statistically significant impact on defining the quality label in the function of making a decision on the purchase of food and organic products.

$\mathbf{H}_{3}$ : The expectations about the product quality, composition of raw materials, freshness, geographical origin and price have a statistically significant impact on the quality label as a factor for making a decision on the purchase of food and organic products.

$\mathbf{H}_{4}$ : Quality label - Verified origin from Vojvodina has a statistically significant impact on the consumers' choice in the purchase of food and organic products.

The established research hypotheses are illustrated by the next research model (Figure 1).

\section{Variables and Measuring Instruments}

The research involved a large number of variables for testing the hypotheses as accurately as possible. An independent grouping variable represents exogenous (demographic) indicators of consumers such as: income, level of education, number of household members, place of resi-

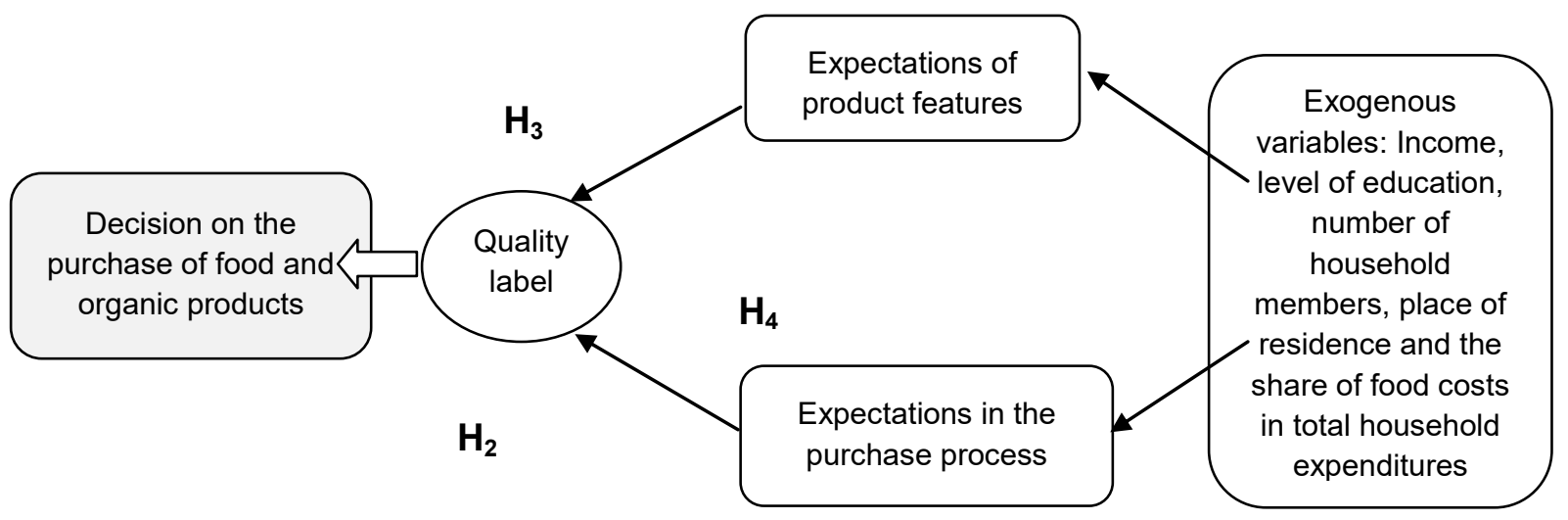

Figure 1. Schematic presentation of research model (Source: Author) 
dence and the share of food costs in total expenditures. Independent variables of the interval type of measurement are: place of purchase, brand, product availability, quality, composition of raw materials, freshness, geographical origin and price. These independent variables have been selected for testing based on the results of related studies that show their significant impact on the expectations and purchasing habits of consumers (Leda and Gomes, 2017; Šojić, 2017; Grubor and Đokić, 2015; Grubor et al., 2014; Stojanović and Ognjanov, 2012; Lukić, 2012; Vlahović et al., 2011; Verbeke, 2005). The individual contribution of each indicator is estimated on the basis of the Likert scale (1-5 rank). Consumer expectations, quality label and decision to purchase food and organic products from local sources appear as dependent variables. Dependent variables are also operationalized through four Likerttype items. Dependent variables have been selected based on the results of the research done by Drexler et al. (2017) and Stojanović and Ognjanov, (2012), which show a statistically significant correlation between these indicators and consumers' expectations in terms of trust in the quality and origin of food and organic products. The choice of questions in the questionnaire, as well as the application of the Likert scale have been selected on the basis of previously conducted tests in related research studies (Grubor and Đokić, 2015; Stojanović and Ognjanov, 2012; Lukić, 2012; Vlahović et al., 2011).

\section{Research Sample Characteristics}

The conducted research includes 486 respondents from the area of AP Vojvodina. Descriptive statistics indicate that there are more women $(n=322 ; 66.3 \%)$ than men $(n=164 ; 33.7 \%)$. The largest number of respondents has higher education $(n=284 ; 58.4 \%)$. A total of 28 different municipalities from AP Vojvodina are included in the research. For the purpose of further analysis, respondents are divided into several groups: respondents coming from municipalities with more than 100,000 inhabitants, municipalities with 50,000 to 100,000 inhabitants, and respondents from places with up to 50,000 inhabitants.
Respondents state that they live in households from one to five members. Household on average has 3 members $(M=2.72$; $S D=1.33$ ). Most of the respondents earn between RSD 30,000 and RSD 60,000 within a household, and from the earned money, households on average spend RSD 38,552 per month on food products, out of which $32 \%$ is allocated for buying fruits and vegetables.

\section{Procedure and Statistical Data Processing}

The research of the participants' views is conducted in the period September October 2018 in the area of AP Vojvodina, as part of the research within the project "Study on sustainability of domestic producers and trade companies in the food and organic products placement in the AP Vojvodina market", which is part of the cycle of Short-Term Projects of Special Interest for Sustainable Development in AP Vojvodina in 2018. Respondents are surveyed electronically on the basis of equestionnaire and field survey. The data collected is sorted and processed with the SPSS 20 statistical package. Respondents' answers are described by descripttive statistics, while the accuracy of hypotheses is tested by different statistical methods: One-way analysis of variance, Pearson's correlation and Multiple linear correlation.

\section{RESULTS}

Based on the summarized answers of the respondents, it is established that end consumers mostly agree with the claim that they purchase food and organic products of domestic origin due to freshness $(M=4.22 ; \quad S D=0.96)$, quality $\quad(M=3.96$; $\mathrm{SD}=0.99$ ) and trust in the composition of raw materials $(M=3.67 ; S D=1.15)$. The decision to purchase food products is mostly affected by their availability $(\mathrm{M}=4.17$; $\mathrm{SD}=0.74)$, price $(\mathrm{M}=3.95 ; \mathrm{SD}=1.03)$ and habit $(M=3.79 ; \quad S D=0.96)$. Respondents confirm that they buy fresh fruits and vegetables mostly at markets $(M=3.88$; $S D=1.19$ ) and that the supply of fruits and vegetables meets their expectations $(M=3.91 ; S D=0.97)$. The highest ranked indicators to which consumers are paying 
attention when purchasing are composition of raw materials $(\mathrm{M}=3.82 ; \mathrm{SD}=1.22)$, brand $(\mathrm{M}=3.83 ; \mathrm{SD}=1.26)$, geographical origin $(M=3.64 ; S D=1.39)$ and quality label $(\mathrm{M}=3.27 ; \mathrm{SD}=1.46)$.

It is significant that consumers' decision to choose foreign rather than domestic food and organic products is not predominantly affected by lower prices $(\mathrm{M}=2.67$; $S D=1.28)$, better organoleptic properties $(M=2.36 ; S D=1.19)$ and more attractive and convenient packaging $(\mathrm{M}=2.34$; $S D=1.26)$. Consumers support the concept of introducing a regional quality label $(M=4.13 ; S D=1.25)$ and agree a segment of the price of products from local sources to be allocated to support environmental protection and other issues related to regional development $(M=4.10 ; S D=1.21)$.

Based on the established hypotheses, it is analysed whether the differences in the tested indicators significantly reflect the differences in consumers' expectations in the selection of food and organic products from local sources and the acceptance of the regional quality label Verified origin from Vojvodina.

First, it is analysed whether income, level of education, number of household members, place of residence and the share of food costs in total household expenditures have a statistically significant impact on the level of consumers' expectations in the purchase of food and organic products $\left(H_{1}\right)$. Pearson's correlation is most suitable for analysing correlation between income, levels of education, the share of food costs and consumers' expectations. It is found that household's total monthly income is significantly correlated to the expectations regarding the product characteristics, such as price $(r=-0.306, p<0.01)$, quality $(r=0.731, p<0.01)$ and freshness $(r=0.981$, $\mathrm{p}<0.01)$. When it comes to price, correlation is statistically significant and negative, i.e. respondents who pay more attention to the price have on average lower income. However, speaking of expectations regarding the purchasing process, there is a statistical significant correlation between income and the place of purchase $(r=0.047, \quad p<0.05)$ and product brand $(r=0.692, p<0.01)$. Furthermore, approximate monthly amount spent on the purchase of food and organic products at the household level is statistically significant and negatively correlated to the price expectations $(r=-0.392, \quad p<0.01)$, while it is positively correlated to the expectations regarding satisfaction with quality $(r=0.263, \quad p<0.05)$, geographical origin $(r=0.235, p<0.05)$ and the composition of raw materials $(r=0.319$, $p<0.01)$. The results of the tests showed that the respondents do not differ in relation to the level of education. Detailed test results are presented in the following table (Table 1).

One-way variance analysis is conducted, since an ordinal scale with three subgroups is applied for the remaining indicators: less than 50,000 , from 50,000 to 100,000 and over 100,000 inhabitants for the place of residence, i.e. 1 member, from 2 to 3 members and over 4 members for the number of household members. Highest expectations of product in terms of quality $(F=4.239 ; p<0.05)$, composition of raw materials $(\mathrm{F}=3.547 ; \mathrm{p}<0.05)$ and availability $(F=5.190 ; p<0.01)$ are held by consumers from smaller towns, while consumers from urban areas prefer place of purchase $(F=10.818 ; p<0.01)$ and product brand $(F=6.003 ; p<0.01)$. When it comes to the second indicator, households with four or more members show the highest dependence on the composition of raw materials of food products $(F=4.561$; $p<0.01)$, freshness $(F=5.925 ; p<0.05)$ and quality $(F=5.127 ; p<0.01)$. Based on the analyses carried out, it can be concluded that the hypothesis $\mathbf{H}_{1}$, is confirmed, i.e. that demographic variables such as income, number of household members, place of residence and share of food costs in total household expenditures have a statistically significant impact on the level of consumers' expectations. We conclude that information on the demography of the AP Vojvodina market may help predict the level of expectations of certain categories of end consumers in the selection of food and organic products. To determine the extent to which place of purchase, brand and product availability as the purchase process variables affect the definition of the quality label $\left(\mathbf{H}_{2}\right)$, a multiple regression analysis is conducted. In the group of predictors, there are items relating to con- 
sumers' expectations from the purchasing process, such as: place of purchase, brand and product availability, while the criterion variable is the decision to purchase food and organic products on the basis of the quality label.

The applied multiple regression analysis showed that a set of independent variables predicted $46 \%$ of the dependent variable. The regression equation is statistically significant $(F=4.267, p<0.01)$. Table provided below Table 2) presents contributions of individual variables.

Statistically significant contributions of the variables are reflected in the product brand $(\beta=0.288, p<0.01)$ and availability $(\beta=.771, p<0.01)$, on the basis of which it can be concluded that the second research hypothesis $\mathbf{H}_{\mathbf{2}}$ is partially accepted and that end users correlate quality label with product brand and availability, while the place of purchase does not represent a significant variable that should be a predictor of quality.

Consumers expect from manufacturers and trading companies to facilitate their decision-making in the process of purchasing by labelling of food and organic products with an emphasis on quality and sources of supply, i.e. the characteristics of the domestic product brand.

They e-pect a high level of reliability of the offered quality which in combination with the availability and display of food and organic - products represents the most im-

Table 1.

Differences in consumers' expectations when buying food and organic products

\begin{tabular}{|c|c|c|c|c|}
\hline \multicolumn{2}{|c|}{ Expectations } & \multirow{2}{*}{$\frac{\text { Income }}{0.047^{*}}$} & \multirow{2}{*}{$\begin{array}{c}\begin{array}{c}\text { Level of } \\
\text { education }\end{array} \\
0.065\end{array}$} & \multirow{2}{*}{$\begin{array}{c}\begin{array}{c}\text { Share of food } \\
\text { costs }\end{array} \\
0.258\end{array}$} \\
\hline & Pearson's correlation & & & \\
\hline Place of purchase & Significance & 0.042 & 0.544 & 0.584 \\
\hline \multirow{2}{*}{ Brand } & Pearson's correlation & $0.692^{* *}$ & -0.153 & 0.742 \\
\hline & Significance & 0.004 & 0.158 & 0.108 \\
\hline \multirow[b]{2}{*}{ Availability } & Pearson's correlation & 0.128 & -0.220 & 0.051 \\
\hline & Significance & 0.285 & 0.050 & 0.242 \\
\hline \multirow{2}{*}{ Quality } & Pearson's correlation & $0.731^{* *}$ & -0.209 & $0.263^{*}$ \\
\hline & Significance & 0.000 & 0.050 & 0.037 \\
\hline \multirow{2}{*}{$\begin{array}{l}\text { Composition of raw } \\
\text { materials }\end{array}$} & Pearson's correlation & 0.054 & -0.151 & $0.391^{* *}$ \\
\hline & Significance & 0.129 & 0.158 & 0.000 \\
\hline \multirow{2}{*}{ Freshness } & Pearson's correlation & $0.981^{* *}$ & 0.814 & 0.355 \\
\hline & Significance & 0.006 & 0.078 & 0.400 \\
\hline \multirow{2}{*}{ Origin } & Pearson's correlation & 0.586 & -0.029 & $0.235^{*}$ \\
\hline & Significance & 0.887 & 0.789 & 0.011 \\
\hline \multirow{2}{*}{ Price } & Pearson's correlation & $-0.306^{* *}$ & -0.186 & $-0.392^{* *}$ \\
\hline & Significance & 0.000 & 0.081 & 0.000 \\
\hline
\end{tabular}

*significant at the level 5\%; ** significant at the level 1\%

Table 2.

Regression model for evaluating significance of the purchasing process indicators for defining the quality label

\begin{tabular}{llccc}
\hline & Indicators & $\begin{array}{c}\text { Standardized } \\
\text { coefficient Beta }\end{array}$ & $\mathbf{t}$ & Significance \\
\hline (constant) & Retail stores & $0.120^{*}$ & 2.533 & 0.013 \\
Place of purchase & Markets & 0.127 & 1.022 & 0.050 \\
& Purchase directly from the & 0.221 & 1.065 & 0.321 \\
& manufacturer & $0.288^{* *}$ & 2.621 & 0.060 \\
Brand & & $0.079^{* *}$ & 0.771 & 0.010 \\
Availability & & & 0.009 \\
\hline
\end{tabular}

*significant at the level 5\%; ${ }^{* *}$ significant at the level 1\% 
portant factors that enable efficiency and satisfaction in the purchasing process. However, the results indicate that endusers do not attach importance to the place of purchase.

The labelling system does not need to include the place of purchase as an essential element for labelling the quality and origin of food and organic products.

Third research hypothesis $\mathbf{H}_{3}$ on whether the product properties (characteristics) provide for quality label in the function of making a decision on the purchase of food and organic products, is also tested by multiple regression analysis.

The results show that a set of predictor variables (product quality, composition of raw materials, freshness, geographical origin and price) can predict $73.4 \%$ of the criterion variable (quality label). Multiple regression analysis proves to be statistically significant $(F=6.304, p<0.01)$. Table provided below (Table 3 ) presents individual contributions.

The table shows that the highest contribution is provided by variables of quality $(\beta=0.30, p<0.01)$ and the composition of raw materials $(\beta=0.432, p<0.01)$, which implies that consumers expect from quality label to guarantee quality and the compo- sition of raw materials of food and organic products. Freshness and geographical origin appear as less significant variables, while price does not have a significant impact on the decision-making process for choosing food products with guaranteed quality.

The obtained results confirm the third research hypothesis $\mathbf{H}_{3}$ that product characteristics, such as quality, composition of raw materials, freshness, origin and price have a significant impact on the definition of the quality label in the function of making decisions on the purchase of food and organic products.

The last hypothesis $\mathbf{H}_{4}$ implies confirmation of whether the use of a regional quality label named Verified origin from Vojvodina would have a statistically significant impact on consumers' decision to purchase food and organic products from local sources.

This correlation between variables is analysed by Pear-son's correlation (Table 4). Correlation is statistically significant, high and positive $(r=0.632, p<0.001)$. This indicates that the regional label of ori-gin Verified origin from Vojvodina would have a statistically significant impact on the consumers' choice in the purchase of food and organic products.

Table 3.

Regression model for evaluating significance of product properties indicators for defining the quality label

\begin{tabular}{lccc}
\hline \multicolumn{1}{c}{ Indicators } & $\begin{array}{c}\text { Standardized } \\
\text { coefficient Beta }\end{array}$ & $\mathbf{t}$ & Significance \\
\hline (constant) & $0.030^{* *}$ & 2.746 & 0.007 \\
Quality & $0.432^{* *}$ & 0.295 & 0.003 \\
Composition of raw & $0.041^{*}$ & 3.001 & 0.004 \\
materials & $0.129^{*}$ & 0.277 & 0.019 \\
Freshness & -0.005 & 1.171 & 0.045 \\
Geographical origin & & 0.050 & 0.050 \\
Price & & &
\end{tabular}

*significant at the level 5\%; **significant at the level $1 \%$

Table 4

Examining justification of the introduction of the regional quality label

\begin{tabular}{lcc}
\hline & & $\begin{array}{c}\text { Designation of origin } \\
\text { Verified origin from } \\
\text { Vojvodina }\end{array}$ \\
\hline $\begin{array}{l}\text { The designation of origin and confirmation of } \\
\text { quality significantly affect the choice of }\end{array}$ & Significance & $0.632^{*}$ \\
purchasing food and organic products & $\mathrm{N}$ & 0.000 \\
\hline
\end{tabular}




\section{DISCUSSION}

Based on the conducted research and confirmed research hypotheses, consumers from the AP Vojvodina market show a relatively high level of ethnocentrism. They express a clear requirement that a regional quality label Verified origin from Vojvodina should provide a reliable selection of food and organic products, subject to the assumption that it includes all analysed indicators. This implies that the quality label from the consumer's point of view must fully meet their expectations regarding the elements of the purchasing process itself and the properties (characterristics) of domestic products. These results match with the results of related studies that confirm that consumers identify the quality label with the purchasing process and product characteristics (Jan et al., 2018; Krishna and Balasubramanian, 2018; Grubor et al., 2014).

The quality label may have a statistically significant impact if compliance with all standards and procedures in the production and placement of food and organic products is ensured, so that label Verified origin from Vojvodina, as such, guarantees standardized quality, verified composition of raw materials, freshness, proven origin, image of the brand of domestic product and adequate availability, i.e. confirms that the labelled product meets all expectations of consumers' from the AP Vojvodina.

In recent years, through Directive 2000/13/EC, European practice has clearly supported the protection of the designation of origin of all products whose specific characteristics derive from the physical, chemical and organoleptic characterristics, the manner of production and processing, and the region from which they come (Stojanović and Ognjanov, 2012). In accordance with this EU Directive, the labelling of food and organic products is also regulated in Serbia through the Law on Geographical Indications (Official Gazette of RS, 18/2010).

Unlike previous initiatives and attempts to label food products, such as the label The best from Vojvodina from 2004, it is necessary to promote the labelling system which would be the basis for improving the overall image of food and organic products of local, regional and/or national origin. According to consumers' attitudes, imported products have an advantage of the image created and the strength of the global brand (Leda and Gomes, 2017; Grubor and Đokić, 2015), which is related to trust in the confirmed level of their quality. Improving the achieved image of domestic products is impossible without raising the level of consumers' trust in determinants of quality and geographical origin. This indicates that it is necessary, with the institutional support, to implement a labelling system that will fully and uniquely guarantee that the labelled food and organic products meet all the elements that integrate the identified indicators that affect the decision to buy.

An additional mechanism that ensures and guarantees standardized quality are vertical forms of cooperation and integration to be built between domestic businesses as participants in supply chains of food and organic products (Končar et al., 2018). This type of cooperation would represent a basis for improving the structure of domestic production and marketing of food and organic products. By applying more efficient vertical cooperation, producers/processors, agricultural holdings and trading companies could accelerate production and sales flows. Consequently, this would lead to a significant improvement in the volume and structure of sales, with the effect of lowering the overall costs and prices of products from local sources.

Apart from this, a necessary pre-condition for an efficient vertical integration is the connection between enterprises and state bodies and scientific research institutions, whose role would be to standardize and monitor products with a proven level of quality and geographical origin.

\section{CONCLUSIONS}

The need for researching the concept of food and organic products labelling has emerged as a consequence of the increasing importance of retailing, and in particular the sector of the traditional food retailing in the overall economic develop- 
ment of the Republic of Serbia and AP Vojvodina. The main purpose of the conducted research was to identify obstacles to the existing supply of food and organic products in the AP Vojvodina market and point to the importance of different indicators for accepting the concept of labelling products as a confirmation of quality and geographical origin.

The obtained results show that consumers' expectations in the process of purchasing food and organic products, as well as the purchasing process itself, are influenced by various indicators that can be related to the functional characteristics of products and their geographical origin. In addition, the analysis confirms that consumers' expectations regarding the purchasing process and the characteristics of food and organic products can be predicted based on their demographic variables, indicating the possibility of adjusting the supply of domestic products to the target segment of end consumers.

The hypotheses tests confirm the assumption that a future regional quality label should combine indicators such as standardized product quality, confirmed composition of raw materials, freshness, geographical origin, brand and availability. Such a quality label statistically significantly determines the consumers' choice when making a decision to buy food and organic products. At the same time, in order to reduce costs and ensure more efficient placement of domestic products to the end consumer, it is necessary to create an environment for vertical integration by strengthening cooperation between domestic agricultural, processing and trading enterprises as potential holders of certification Verified origin from Vojvodina.

The obtained results and confirmed hypotheses represent the basis for further research which should focus on the ways of building a recognizable image of the regional quality label, developing vertical forms of cooperation between domestic producers, farmers and trading companies, etc. Furthermore, the research should be extended to the national market of the Republic of Serbia. The data obtained through such an extended research would complete the scientific view on the importance of introducing the regional quality label of food and organic products.

\section{ACKNOWLEDGEMENTS}

The paper is the result of the research on the project "Study on sustainability of domestic producers and trade companies in the food and organic products placement in the AP Vojvodina market" which is part of the cycle of "Short-Term Projects of Special Interest for Sustainable Development in AP Vojvodina in 2018“, financed by the Provincial Secretariat for Higher Education and Scientific Research.

\section{REFERENCES}

1. Avedian, N. (2018). Fresh produce retail-analysis of vertical coordination and procurement models in the central california lemon supply chain, PhD Thesis, Kansas State University, College of Agriculture, Kansas, USA.

2. Brčić-Stipčević, V., Petljak, K., Guszak, I. (2011). Kanali distribucije i obilježja tržišta ekoloških prehrambenih proizvoda. $11^{\text {th }}$ International Scientific Conference - Business Logistics in Modern Management, University of Osijek, Faculty of Economics and Business, Osijek, Croatia, Proceedings, pp. 111-125.

3. Directive 2000/13/EC (2000). Official Journal of the European Union, L109/1, 29-42.

4. Drexler, D., Fiala, J., Havlíčková, A., Potůčková, A., Souček, M. (2018). The effect of organic food labels on consumer attention. Journal of Food Products Marketing, 24(4), 441-455.

5. Gašević, D., Tomašević, D., Vranješ, M. (2017). Key factors determining the ethnocentric tendencies of consumers in Serbia. Management: Journal of Sustainable Business and Management Solutions in Emerging Economies, 22 (3), 63-73.

6. Goldman, A., Hino, H. (2005). Supermarkets vs. traditional retail stores: diagnosing the barriers to supermarkets' market share growth in an ethnic minority community. Journal of Retailing and Consumer Services, 12 (4), 273284.

7. Grubor, A., Đokić, N. (2015). Determinants of choice of global and national food products' brands. Strategic Management, 20 (2), 58-67.

8. Grubor, A., Đokić, N., Milićević, N. (2014). Specifičnosti segmentacije tržišta prehrambenih proizvoda. Marketing, 45, 139-146.

9. Krishna, R., Balasubramanian, P. (2018). The significance of factors influencing consumer behaviour towards organic food products in Kochi. International Journal of Pure and Applied Mathematics, 119, 2641-2665.

10. Končar. J., Leković. S. (2013) Trendovi modernizacije i strukturne transformacije trgovine u 
funkciji održivog razvoja. Anali Ekonomskog fakulteta u Subotici, 49, 407-419.

11. Končar, J., Marić, R., Vukmirović, G. (2018). Izazovi vertikalne integracije učesnika lanaca snabdevanja prehrambenih i organskih proizvoda nacionalnog porekla. Anali Ekonomskog fakulteta u Subotici, 54, 149-169.

12. Kopić, M., Cerjak, M., Mesić, Ž. (2008). Zadovoljstvo potrošača ponudom ekoloških proizvoda u Zagrebu. XLIII hvatski i III međunarodni simpozij agronoma, Opatija, Hrvatska, Zbornik radova, 43 , pp. $1-5$.

13. Kraleva, V. (2017). Understanding voluntary simplifiers in Bulgaria. Marketing and Business Development Journal, 3 (1), 90 - 96.

14. Leda, L.C., Gomes, J. (2017). Traditional food trade: advances in the counter-current. $R e-$ tratos de Assentamentos, 20 (2), 13-30.

15. Lukic, R. (2012). Sustainable development of retail in Serbia. Revista de Management Comparat International, 13 (4), 574-586.

16. Milin, B. (2018). Etnocentrizam starijih hrvatskih potrošača, Doktorska disertacija, Sveučilište u Dubrovniku, Departman za ekonomiju i poslovnu ekonomiju, Dubrovnik, Hrvatska.

17. Marinković, V. (2017). Efekti animoziteta prema Evropskoj Uniji i patriotizma na potrošački etnocentrizam građana Republike Srbije. Ekonomski horizonti, 19, 3-15.

18. Martić Kuran, L., Mihić, M. (2014). Primjena teorije planiranog ponašanja u kupovini ekološke hrane. Market-Tržište, 26, 179-197.

19. Ricci, E.C., Banterle, A. (2018). The effects of expo Milano 2015 on consumer food choices. Economia Agro-Alimentare, 20 (2), 233-244.

20. Patterson, P.H. (2018). The supermarket as a global historical development: Structures, capital and values. In The Routledge Companion to the History of Retailing. Eds. J. Stobart, V. Howard, Routledge, London, pp. 172-197.

21. Petković, G, Lovreta, S., Pindžo, R., Pešić, S. (2016). Analiza koncentracije u sektoru turizma i maloprodaje robe široke potrošnje u Srbiji. Ekonomika preduzeća, 64 (1/2), 187-198.

22. Peyer, M. Balderjahn, I., Seegebarth, B., Klemm, A. (2017). The role of sustainability in profiling voluntary simplifiers. Journal of Business Research, 70, 37-43.

23. Stojanović, Ž., Ognjanov, G. (2012). Strateška opredeljenja Srbije u domenu ruralnog razvojaproizvodnja i marketing tradicionalne hrane. Economic Themes, 50 (1), 19-32.

24. Schnettler, B., Miranda, H., Lobos, G., Sepúlveda, J., Denegri, M. (2011). A study of the relationship between degree of ethnocentrism and typologies of food purchase in supermarkets in central-southern Chile. Appetite, 56 (3), 704-712.

25. Šojić, S. (2017). Kreiranje branda organskih poljoprivredno-prehrambenih proizvoda u Republici Srbiji, Doktorska disertacija, Univerzitet u Novom Sadu, Poljoprivredni fakultet, Novi Sad, Srbija.

26. VanBerkum, S., Bogdanov, N. (2012). Serbia on the Road to EU Accession: Consequences for Agricultural Policy and the Agri-Food Chain, CABI, Cambrige, USA.

27. Vlahović, B., Puškarić, A., Jeločnik, M. (2011). Consumer attitude to organic food consumption in Serbia. Bulletin: Economic Sciences Series, 43 (1), 45-52.

28. Veljković, S. (2009). Uticaj etnocentrizma na potrošače u Srbiji. Marketing, 40 (2), 97-106.

29. Vermeir, I., Verbeke, W. (2006). Sustainable food consumption: Exploring the consumer "attitude-behavioral intention" gap. Journal of Agricultural and Environmental Ethics, 19 (2), 169-194.

30. Verbeke, W. (2005). Consumer acceptance of functional foods: socio-demographic, cognitive and attitudinal determinants. Food Quality and Preference, 16 (1), 45-57. 


\title{
МОГУЋНОСТИ УНАПРЕЪЕЊА ИМИЏА ПРЕХРАМБЕНИХ И ОРГАНСКИХ ПРОИЗВОДА НА ТРЖИШТУ АП ВОЈВОДИНЕ КРОЗ УВОЪЕЊЕ РЕГИОНАЛНЕ ОЗНАКЕ КВАЛИТЕТА
}

\author{
Јелена А. Кончар, Александар Б. Грубор, Раденко М. Марић*, Горан М. Вукмировић, \\ Ненад С. Ђокић
Универзитет у Новом Саду, Економски факултет у Суботици, 24000 Суботица, Сегедински пут 9-11, Србија

\begin{abstract}
Сажетак: Процеси интернационализације утичу на вишеструко увећање понуде прехрамбених и органских производа на националним тржиштима, што се одражава на повећање нивоа конкуренције између увозних производа и производа националног порекла. Као резултат тога, пред потрошачима се налази избор веома широке понуде готових производа за коју нису у могућности да са сигурношћу утврде све аспекте квалитета и порекла. Циљ истраживања је идентификовање препрека и недостатака постојеће понуде прехрамбених и органских производа на тржишту АП Војводине, анализа склоности домаћих потрошача ка куповини производа националног порекла и утврђивање сигурност потрошача у концепт означавања производа као потврде квалитета и географског порекла. Емпиријским истраживањем је обухваћено испитивање ставова 486 крајњих потрошача на тржишту АП Војводине у вези са њиховим очекивањима и навикама када приступају куповини прехрамбених и органских производа. Као резултат истраживања очекује се утврђивање значаја различитих индикатора за покретање система означавања производа који су на традиционалан начин и уз поштовање прописаних услова произведени и пласирани на тржишту АП Војводине.
\end{abstract}

Кључне речи: прехрамбени производи, органски производи, ознаке квалитета, поверење, куповне навике, проверено из Војводине

Received: 19 December 2018

Received in revised form: 31 January 2019

Accepted: 20 February 2019 